\title{
Need of post-consumer textile waste management via circular economy
}

\author{
Dr. Asiya Chaudhary ${ }^{1}$ and Mushahid Ali Shamsi ${ }^{2}$
}

${ }^{1}$ Aligarh Muslim University, Department of Commerce, Aligarh Muslim University Campus, Aligarh 202002 (Uttar Pradesh), India.

${ }^{2}$ Aligarh Muslim University, Department of Commerce, Aligarh Muslim University Campus, Aligarh 202002 (Uttar Pradesh), India.

\section{To Cite this Article}

Dr. Asiya Chaudhary and Mushahid Ali Shamsi, "Need of post-consumer textile waste management via circular economy", International Journal for Modern Trends in Science and Technology, 6(9S): 197-213, 2020.

\section{Article Info}

Received on 25-August-2020, Revised on 08-September-2020, Accepted on 12-September-2020, Published on 18-September-2020.

\section{ABSTRACT}

Prosperity leads to extravagance. With economic development and escalating purchasing power of consumers and expanding manufacturing sectors, demand for textiles and apparel are mounting day by day. No doubt it boosts economies of nations, yet at the same time results in loads of textile waste to unprecedented levels which is categorized into Pre-consumer \& Post-consumer textile waste. This surge Socio-economic and environmental problems, while it will be converted into an opportunity by adopting Circular Economy in Textiles manufacturing, which is virtually missing from many economies of the world, especially from Indian Economy that's why a primary based exploratory research was conducted in India with 260 samples that were collected from selected cities of Indiato explore quantity, reasons and methods used to dispose off Post-consumer textile waste. It identifies consumers' awareness and inclinations towards Circular Economy. The outcome depicts that an average consumer discards (most often donate) around 6 pieces in a year with limited options. Their ignorance, absence of alternative options and lack of government role worsens the situation. The study has strong implications, generating awareness for the Circular Economy and attracting entrepreneurs and Nations Government to frame policies and provisions that would encourage investment on plants, technology and training on Circular Economy. This study would definitely open avenues for small \& Medium scale entrepreneurs, generate employment and above all produce sustainable textiles and create a sustainable environment via Circular Economy.

KEYWORDS: Circular Economy; Post-Consumer textile Waste; Textiles Waste management; Circular Textiles Economy; Sustainable Environment. 


\section{INTRODUCTION}

The textile industry is a significant contributor in different economies of the world interms of trade, employment, investment and revenue this can be easily seen by the size of the global apparel market which is 1685 billion USD in 2015 (Statista, 2018; Walter, et al., 2019).This convert textile industries into complex and polluting industries, Complex because they encompass a long and variegated production of textile products, textile manufacturing, garment making, distribution and disposal (Prerna \& Charu, 2018) and Polluting because they use

adverse effects, whereas this needs to be recycled or up-cycled like other toxic or nontoxic and harmful liquid or solid waste (Prerna \& Charu, 2018). This state of affairs highlights the need of textile recycling. Recycling of textile not only bring environmental and ecological advantages but also brings many other benefits of a socio-economic nature because every phase of the life cycle of textile waste recycling (i.e. collection, sorting, transport, recycling) generates employment and gives opportunities for small or medium businesses (Cuc and Vidovic, 2011; Zamani, 2014).More often, textile recycling is considered not as an end in itself, but as a way to implement the Circular Economy, i.e. a closed loop production system. It might become one of the keys that help companies in the process of moving towards sustainable business. Textile recycling reduces the cost of textile manufactured products, depending on recyclable materials being a low-cost and efficient alternative with no or little environmental impact (Walter, et al., 2019).

This study is conducted in India because Indian textiles industry boasts of its rich heritage and forms a leading sector in Indian economy. 2018-19 data reflects that the industry is estimated at approximately 150 billion \$ (Indian Textiles Report-Feb, 2020), contributes $7 \%$ to the industrial output, $2 \%$ of the GDP, $15 \%$ of the total export earnings and employs more than 45 million people directly (Ministry of Textiles, Annual Report 2018-19). With economic prosperity, textile consumption has touched new records, resulting in loads of textile waste to unprecedented levels. In addition to socio-cultural factors, fashion also adds up to the ever-increasing antiquated stocks. As per Indian Textiles Journal 2011data, more vastquantity of water, chemicals and pollute ecosystem (Boström and Micheletti, 2016).

Textile or Apparel consumption has increased intensely over the last few decades, leading to the intense increase in textile waste in most cities of the world (Bukhari et al., 2018). This is due to the unawareness of many consumers about sustainable consumption and disposal methods of textiles (Mo et al., 2009). The ineffective disposal methods of textiles are gradually a serious problem in many parts of the world (Birtwistle and Moore, 2007; Chen-ke, et al., 2019)because it increases the quantity of textile waste which (1) has variou than one million tons textiles are disposed per annum based on estimates with significant contribution from the household sector (Mitali, 2019).

\section{A. Textile Waste}

Waste is simply garbage which consists of everyday rejected items, likewise textile waste is an unusable clothes or material that is considered useless by the owner. Pragmatically, textiles waste is being influenced successively by its production and consumption activities, which is categorized as Pre-consumer \& Post-consumer textile waste (Agrawal\&Sharan, 2015; Bairagi, 2014).

\section{Pre-consumer textile waste}

Pre-consumer textile waste also called post-industrial waste/ manufacturing waste, this waste is produced either on various steps of the distribution chain before the final product reaches the consumer or it is generated during the process of production from spinning and weaving to cut-make-sew operations.It includes garment cutting excess, yarn waste, trimmings, end of rolls print trials, production surplus and errors in dye lots (Kapila \& Dhillon, 2019; Berthon, 2016). "On an average, around $15 \%$ of fabric used in garment production is discarded and wasted in the process which contributes to post-industrial waste" (Beitch, 2015; GUPTA, 2018).

\section{Post-consumer textile waste}

Post-consumer textile waste, also called dirty waste and household waste because it is generated by consumers at household level. It includes clothing, household articles or anything that is made up from manufactured textile that the owner decides to discard. These 
clothing/articles are being rejected in view of either they get damaged, run out of fashion or worn out (Kapila \& Dhillon, 2019; Berthon, 2016).The discarded can also be at times given for further use through charity deeds sometimes given to charities but more typically they are disposed off into the trash and end up laying in municipal landfills (GUPTA, 2018).

These two levels surge textile waste adding hugely to environmental problems (Dobilaite, et al., 2017)because, production of textiles includes vast use of energy, water and chemicals, direct $\mathrm{CO} 2$ emissions and solid waste (Resta, et al., 2016). The intensity of their ecological footprint varies depending on the stages of the textiles or clothing product life cycle (Koszewska, 2018).

\section{B. Circular Economy}

Circular economy is a concept that changes the production process, reduces the use of virgin raw material in production (Snoek, 2017) and provides significant economic benefits (Vasileios, et al., 2015) because it converts waste into a useful raw material by recycling it (Fashion, 2018). Besides, it contributes towards the sustainability of environmentand society because of its circular approach

produce-use-dispose-repair-regenerate-reuse

(Cyberpac, 2013).It also brings sustainability in production processes which will lead to various socio-economic advantages not only in industries, but in societies too (Agrawal\&Sharan, 2015; Walter, et al., 2019).

The reuse and recycling of textiles might be considered as a way to socio-economic benefits and a source of boosting a nation's economy (Cuc and Vidovic, 2011).A report commissioned by the European Union, consultancy firm McKinsey estimates that the conversion into a circular system possibly will generate a net economic benefit of $€ 1.8$ trillion by 2030 (McKinsey, 2015). Recently, Club of Rome reports have concluded that the circular economy would deliver socio-economic benefits in the form of higher energy efficiency, reduced carbon emissions and the creation of employment in the EU (Wijkman \& Skånberg, 2016).In economic system like textile industries, fiber and fabric recycling is fully implemented with the objective to reduce resource needs (water, fossil fuels, chemicals) and to create new jobs in the collecting, sorting and recycling of clothing (Ellen McArthur Foundation, 2017; Walter, et al., 2019)

Post-consumer textile waste management has been an area of concern, which seeks immediate attention to tackle pollution issues (Xu, et al., 2019; Bukhari, et al., 2018) and efficiently convert waste into a useful raw material which can be reused in fabricating fresh textile (Assmuth, et al., 2011; Vasileios, et al., 2015; Dahlbo, et al., 2017; GUPTA, 2018.) and no doubt also helps in adopting Circular Economy that promotes Repair, Regeneration and Reuse of products instead of using traditional Linear Economy which means Produce-Use-Dispose (Geissdoerfer, 2017; Mitali, 2019). According to the Mitali, 2019 report,like others in the world, the textile industry is the third largest cause of waste generation in India after paper, plastic and compost waste. Despite this, concept of circular economy is nearly absent in Indian textile industry. Recycling of textiles was done as a domestic craft in India like making rugs, mats, bags, wipes and dusters etc. from unwanted or used clothes (Bairagi, 2014; PRERNA \& CHARU, 2016).The market that follows a circular economy is the one in Panipat wherein they recycle woollens and turn them into blankets but China performs much better in terms of variety and cost (Minter, 2018). The other unit is in Tamil Nadu "A Finnish company turns trash into fashion business, transforms leftover fabrics \& used clothing into new and usable pieces of clothing" (Esha, 2016) but these practices are not enough compared to the volume of textile waste creation. The poor adoption of Circular Economy is due to lack of awareness among Indian consumers and producers, as well as dearth of government's initiatives (PRERNA \& CHARU, 2016).

The study confines its scope to the consumers of top 5 populated cities of India namely Mumbai, Delhi, Kolkata, Chennai and Bangalore with the objectiveto examine the quantity of Post-consumer textiles waste generated by an individual annually. It identifies the reasons and methods adopted by consumers to dispose off their unwanted clothing. It further explores awareness of consumers regarding Circular Economy and their willingness to put efforts into adopting it. The study also measures their opinion in respect to the challenges and advantages of adopting Circular Economy. 


\section{THEORETICAL BACKGROUND}

A. Pre-Consumer and Post-Consumer textile waste and its management

There is an upsurge in textile waste (Xu, et al., 2019) because of fast changing fashion trends or consumer's changing demands (Fashion, 2018; Lau, 2015) and metamorphoses into various environmental problems (Dobilaite, et al., 2017)which need to be managed effectively. The various studies like Bairagi, 2014; Agrawal\&Sharan, 2015; Dobilaite, et al., 2017 categorize textile waste into two categories i.e. Pre-consumer textile waste and Post-Consumer textile waste on the basis of places where it has been created i.e. at industries and at households respectively. Bhattacharjee in 2011 outlined four common ways of textile waste management and these are: Source Reduction; Recycling; Landfill; and Incineration. The first two methods are either to minimize or reuse the textile waste, which is safe enough, whereas the next two ways produce leachate, dioxins, heavy metals, acidic gases and dust particles which are substantially harmful for humans as well as for the environment. Bairagi (2014)in his study highlighted the application of Pre-consumer textile waste and Recycling practices of Post-Consumer textile waste in India. Agrawal, R.\&Sharan, M. (2015) explain how the concept of textile waste management helps in protecting the environment, reduces the cost of production and provides other monetary benefits to companies and consumers. Prerna \& Charu (2018) discussed various causes of textile waste generation and various socio-economic benefits of this waste management in their study, which will motivate many start-ups and researchers to work in this direction.

\section{B. Circular Economy and recycling of textile}

The textile industry is considered as one of the most complex and polluting industry (Chen-ke, et al., 2019; Boström \& Micheletti, 2016; GUPTA, 2018) because all its activities from production to consumption generates waste and affects the environment (Dobilaite, et al., 2017; GUPTA, 2018). Boström \& Micheletti (2016) \& Chen-ke, et al. (2019)in their studies gave the reasons why production and consumption of textile is environmentally a damaging process as its production uses vast quantity of water, chemicals and natural resources and on the other hand consumption includes incompetent usage patterns. Despite this, waste is ever augmentinginmost cities of the world because of dramatic expansion in clothing consumption(Bukhari, et al., 2018) and unawareness of consumers about the sustainable consumption \& disposal methods (Mo, et al., 2009) that also fabricate serious problems in many parts of the world (Birtwistle \& Moore, 2007; Chen-ke, et al., 2019). Millions of tons of textiles waste are generated every year in the worldwitharound 20 million tons of Pre- and Post-consumer textile waste generated solely by China annually. (REDRESS, 2014).

Fletcher (2012), Laitala et al. (2015), and Dahlbo, et al. (2017),gave directions to reduce adverse environmental impacts of this waste in phases and GUPTA (2018)study convince that 5 R's of textile waste management are essential tools to tackle the concern of textile waste. These are: rethink, reduce, recycle, reintroduce and reuse. Ideally, recycling and reuse of textile waste can trim the use of fresh materials in the production of new textiles, reducing the use of water, energy, natural resources and chemicals during the production (Assmuth, et al., 2011; Dahlbo, et al. 2017). Currently, as the global resources are shrinking, waste is considered as a resource that can be globally utilized (Klemeš, et al., 2010; Almeida, et al., 2013; Govindan, et al., 2014; Bing, et al., 2015). As a result, recycling is one of the effective methods to ameliorate the waste management systems (Klemeš, 2012), to sustain the environment for future and break into eco-friendly contexture (Kreiger, et al., 2014; Sandin \& Peters, 2018; Dias, et al., 2018; Polat, et al., 2018). According to Hamed, J. (2019), natural resource like cotton are subsiding and textile industries is leaving no stones unturned to search substitute for these resources, consequently, recycling process has been galvanizing significant attention (Leng, et al., 2018; Li, et al., 2016; Rahimi \& Ghezavati, 2018; Bostanci, et al., 2018). Circular Economy is a broader concept of which recycling becomes a part.Boulding, K.(1996)was among the first authors to express the circular economy as a 'spaceman economy' that would operate by reproducing the initial limited stock of inputs and recycling waste outputs. This novel conception alters the production process, reduces the use of virgin resources as a raw material(Snoek, 2017)and helps in recycling the waste to re-enter as a resource in the economy to a large extent, rather than ending up as a waste 
(Fashion, 2018).According to Vasileios, et al. (2015) 'Circular Economy' is catching attention as a concept at both academic and policy circles, as circular business models engender significant economic benefits whichalso explained by Walter, et al. (2019), in his study entitled- 'A review on socio-economic, environmental and ecological advantages brought by recycling of textiles'. FICCI along with NITI Ayog also made attempts to address these challenges in India via Circular Economy Symposium in 2018 (Symposium, 2018).

\section{RESEARCH METHODOLOGY}

\section{A. Sample and data collection}

The study adopted descriptiveresearch design, conducted in top 5 populated cities of India and these are Mumbai, Delhi, Kolkata, Chennai and Bangalore according to the Census 2011 of India (Office of the Registrar General and Census Commissioner, India., 2011). It is primary and descriptive in nature, used simple questionnaire to collect the required information and to illustrate the objective of the study. Online survey i.e. Google forms were shared on social networking sites like Facebook, Instagram, WhatsApp and emails. Non-probability convenient sampling to 9, 5-point Likert scale is adopted with options: 1 for Never, 2 for Rarely, 3 for Sometimes, 4 for Often and 5 for Very often. Question 10 and 11 use a 5-point Likert scale where respondents have to rate each option according to the troubles and ease, they face while disposing of their textile waste. It is: 1 for strongly disagree, 2 for Disagree, 3 for Neutral, 4 for Agree and 5 for strongly agree. Multiple options were given in Question 12 related to various quantities disposed off by the respondents.

Section 3 consists of 7 questions (13 to 19), which enquires about the awareness, advantages and obstacles of Circular Economy. In question number 13 to 17 dichotomous options i.e. Yes or No are given to the respondents and to answer method has been applied. 350 questionnaires were distributed, out of which 299 (85.43\%) were received back but after data screening we found that $39(11.15 \%)$ questionnaires are with missing frequencies and unengaged responses. Remaining 260 were complete, usable and appropriate for data analysis, representing the satisfactory response rate of $74.28 \%$ which is appropriate in context of analysis.

\section{B. Measures}

The questionnaire consists of three sections:

Section 1 consists of 6 questions (1 to 6), which pertains to the demographic factors of the respondents like gender, age, education qualification, family income per year, marital status and family members. Multiple choice questions are designed for this purpose.

Section 2 consists of the next 6 questions (7 to 12), which are associated with the reasons \& average quantity of textile waste, common ways adopted by respondents to dispose their unwanted, convenience and challenges they face while disposing. To answer the questions from 7

question number $18 \& 19$, a 5 -point Likert scale is used, in which participants rate each option of the question according to their opinion. It assigns 1 for strongly disagree, 2 for Disagree, 3 for Neutral, 4 for Agree and 5 for strongly agree.

\section{Reliability \& Validity testing}

Nunnally and Bernstein (1994) study suggested that the Cronbach's alpha must be more than 0.70 but Perry, et al. (2004) classified reliability on the scale basis in their book 'SPSS Explained' and suggested that if values of Cronbach's alpha is 0.90 - above than it is excellent reliable, if it lies between $0.70-0.90$ than it is High reliable, if it lies between $0.50-0.70$ than it is Moderately reliable and if it is 0.50 - Below that is Low reliable

Table 1. Reliability of Questions

\begin{tabular}{rllc}
$\begin{array}{c}\text { Question } \\
\text { No. }\end{array}$ & \multicolumn{1}{c}{ Questions } & $\begin{array}{c}\text { Cronbach's } \\
\text { Alpha }\end{array}$ \\
\hline 7 & Dispose off their clothes because: & & 0.554 \\
8 & Dispose off children clothes because: & 0.952
\end{tabular}



with them: off my unwanted or used clothes:

Convenient ways for them to dispose off their
unwanted or used clothes, if they are provided with following services in their cities: unwanted and used clothes because:

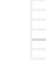

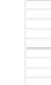

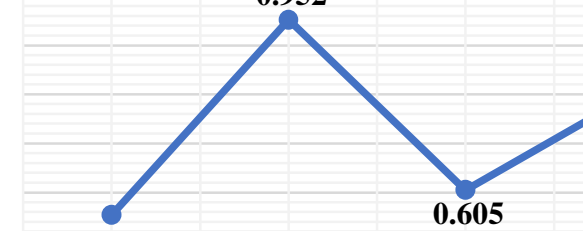

0.554

0.605

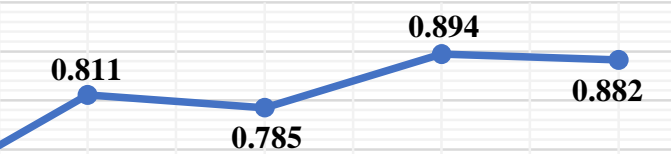

.

.

7

10

11

18

19

Questions

$\longrightarrow$ Cronbach's Alpha

Figure 1. Reliability Status of Questions

In order to check internal consistency and scale reliability, Cronbach's alpha was applied to each question as shown in the above table and figure. In this study Cronbach's alpha lies between 0.554 - 0.952, reflecting the internal consistency and reliability of questions. Out of 7 questions only 2 questions i.e., no. 7 and 9 shows Moderate reliability (values 0.554 and 0.605), other 5 questions No. 8, 10,11, 18 and 19 reflect high and excellent reliability with values $0.952,0.811$, $0.785,0.894,0.882$.
The study is descriptive in nature which uses statistical tools like Arithmetic Mean, percentage methods to conclude the results. Data is collected through questionnaire on the basis of 5-point Likert scale, dichotomous questions and multiple-choice questions.

\section{RESULTS AND DISCUSSION}

A. Results

Section 1:It consists of 6 questions pertaining to the demographic factors of the respondents. 
Table 2: Demographic profile of the Respondents

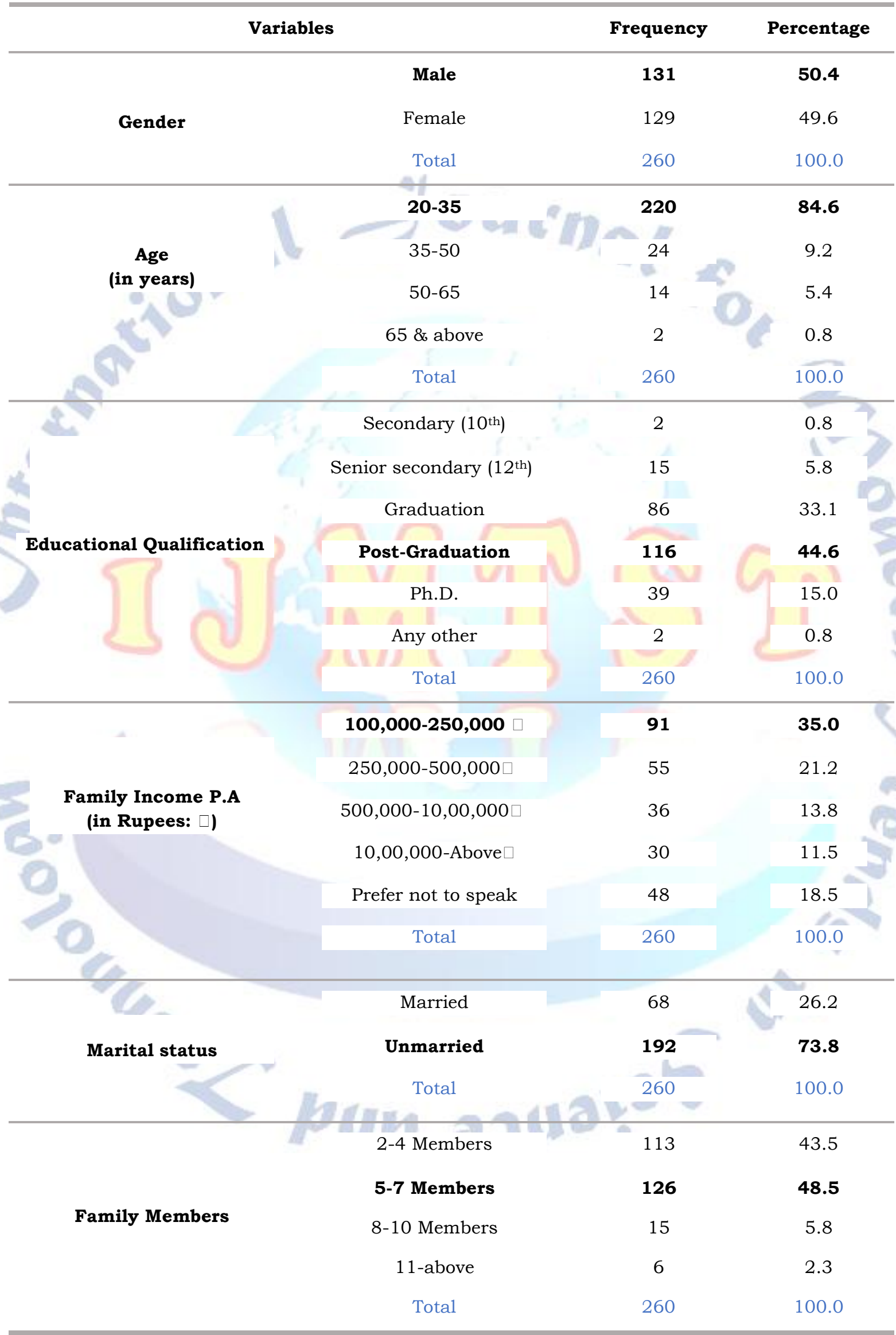


The above table exhibits the data regarding the demographic characteristics of the target population such as Gender, Age, Qualification, Family Income Per Annum (P.A), Marital status and Family Members. Out of 260 respondent's majority of them were male $131(50.4 \%)$ and female respondents were 129 (49.6\%). Large number of respondents lie in the age group of 20-35 years $220(84.6 \%)$ and others between groups of 35-65 or above years 40 (15.4\%). Out of total respondents, majority were pursuing Post-graduation $116(44.6 \%)$ or Graduation $86(33.1 \%)$ and the other respondents were either in Secondary $\left(10^{\text {th }}\right)$, Senior secondary $\left(12^{\text {th }}\right)$ or Ph.D. Only $2 \%$ belonged to any other category 2 $(.8 \%)$. Majority of the respondents $91(35 \%)$ haveannualfamily
betweenRs. $1,00,000-2,50,000,55(21.2 \%)$ have Rs. 2,50,000-5,00,000, and $66(25.3 \%)$ have Rs. $5,00,000-10,00,000$ or above and 48 (18.5\%) respondents preferred not to speak about their Annual family incomes. $192(73.8 \%)$ of the total respondents were unmarried and rest i.e. 68 $(26.2 \%)$ were married. $126(48.5 \%)$ of the respondents had 5-7 Family members, 113 (43.5\%) had 2-4 Family members and the rest i.e. $21(8.1 \%)$ had $8-11$ or above family members.

Section 2:It consists of 6 questions (7 to 12) which are associated with the reasons \& average quantity of textile waste, common disposal methods adopted by respondents, and various conveniences/ challenges experienced by the respondents during disposing off.

Table 3: Why and How people dispose of their unwanted clothes

\begin{tabular}{lll}
\hline Options & Question no. 7: Dispose of clothes because: & Mean \\
\hline 7.A & Of fast changing fashion \& trends & $\mathbf{2 . 4 2}$ \\
7.B & Old clothes fill the space of my wardrobe & $\mathbf{2 . 7 3}$ \\
7.C & They become defective or worned-out & 3.31 \\
7.D & They didn't suit my personality & $\mathbf{2 . 5 0}$ \\
\hline Options & Question no. 8: OPTIONAL: Dispose off $\mathbf{~ m y ~ c h i l d r e n ~}$ & Mean \\
\hline & clothes because: & \\
\hline 8.A & Of fitting issues (tight/short/loose/long) & $\mathbf{5 . 4 7}$ \\
8.B & They did not like them & $\mathbf{5 . 1 8}$ \\
8.C & They were worn out and shabby & $\mathbf{5 . 4 3}$ \\
8.D & Of changing fashion & $\mathbf{5 . 1 8}$ \\
\hline Options & Question no. 9: When I have unwanted old clothes, I: & $\mathbf{M e a n}$ \\
\hline 9.A & Donate them & 3.88 \\
9.B & Sell them & $\mathbf{1 . 3 4}$ \\
9.C & Swap(exchange) them & $\mathbf{1 . 5 7}$ \\
9.D & Use them for various household purposes & $\mathbf{3 . 1 6}$ \\
9.E & Reuse them by modifying it & $\mathbf{2 . 3 9}$ \\
9.F & Throw them in bins & $\mathbf{1 . 6 7}$ \\
9.G & Put them on fire & $\mathbf{1 . 4 4}$ \\
\hline
\end{tabular}




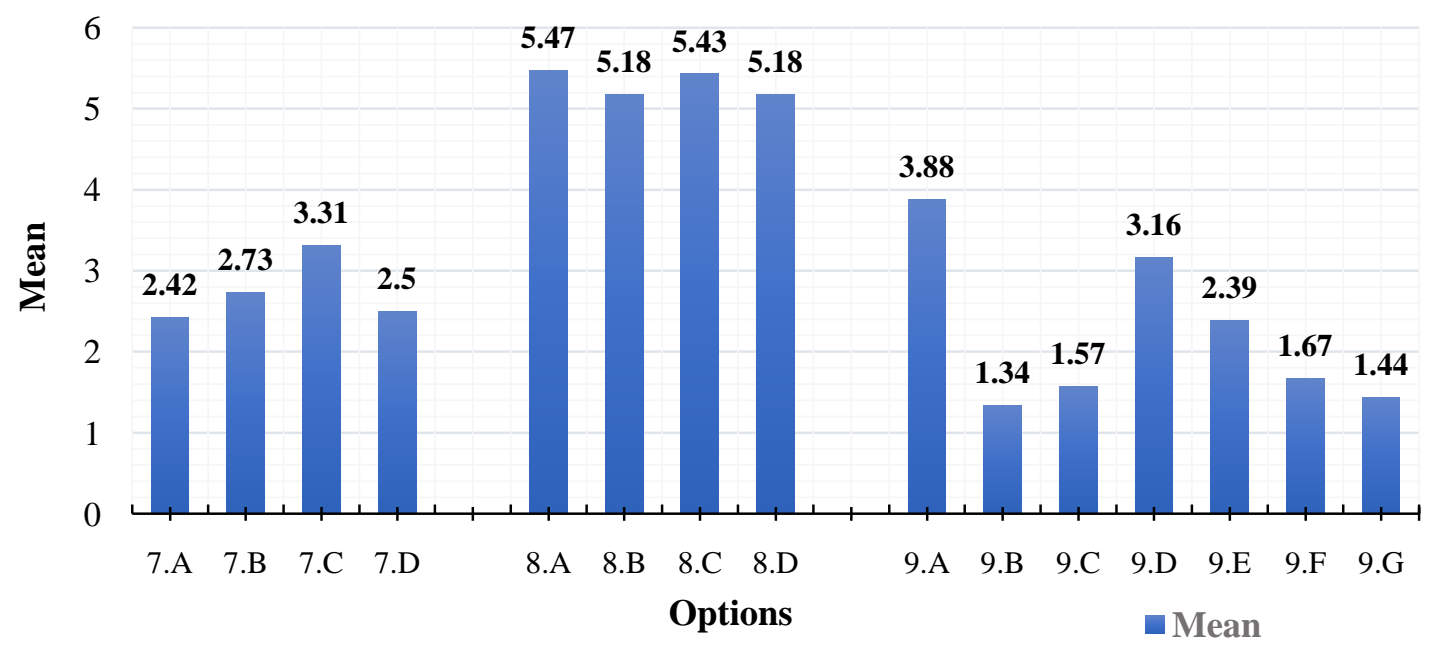

Figure 2. Mean status of Question No. 7, 8 and 9

Question No. 8 is optional which is only filled up by the respondents who had children and out of 260 only $62(23.85 \%)$ respondents had children. After analyzing the Mean of above questions, it is concluded that mostly people dispose off their clothes becausethey became old \& worn out
(Mean $=3.31)$, while they dispose off their children's clothes due to fitting issues (tight/short/loose/long) $($ Mean $=5.47)$ and to get rid they donate them (Mean $=3.88)$ most of the time.

Table 4: Challenges and convenient ways for people to dispose of unwanted clothes.

$\begin{array}{llc}\text { Options } & \text { Question no. 10: Challenges I face when I want to dispose } \\ \text { off my unwanted or used clothes: }\end{array}$




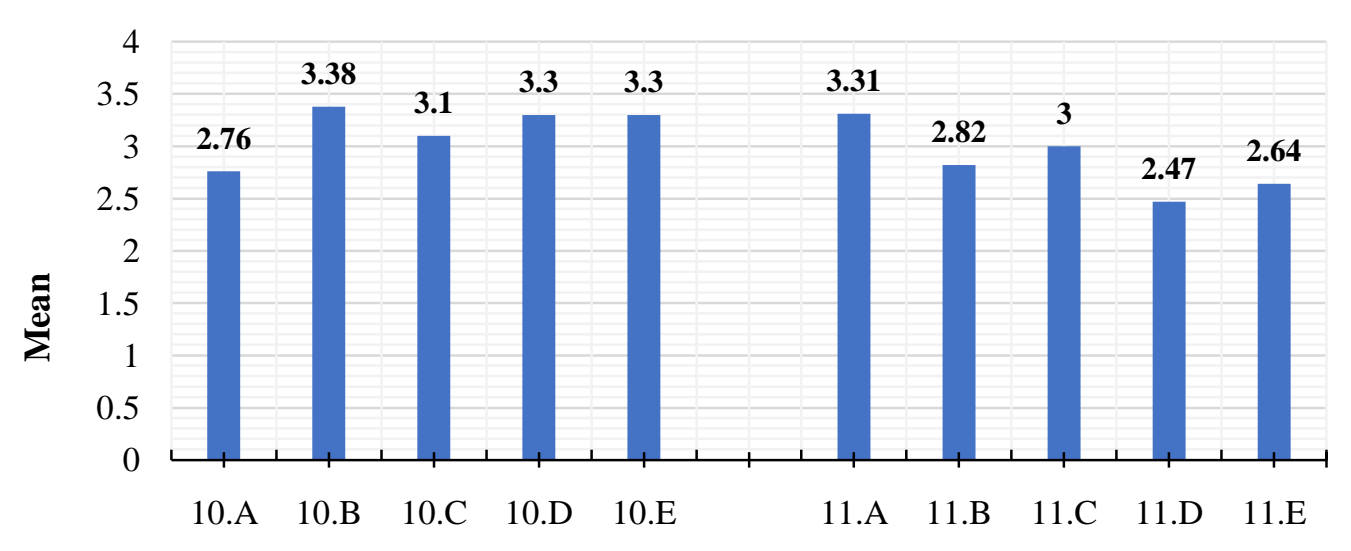

Options

- Mean

Figure 3. Mean status of Question No. 10 and 11

The Means of above questions reflects that the most challenging task for people to dispose off their unwanted/used clothes is to find stores who purchase second hand clothes $($ Mean $=3.38)$ and the most convenient way for people to dispose off their unwanted clothes is the Home pick up services of waste management companies (Mean $=3.31$ ).

Table 5: Total disposal of unwanted or used clothes by respondents in a year.

\begin{tabular}{|cccccc}
\hline $\begin{array}{c}\text { Piece dispose } \\
\text { (in year) }\end{array}$ & $\begin{array}{c}\text { Class } \\
\text { intervals }\end{array}$ & $\begin{array}{c}\text { Mid value } \\
(\mathbf{X})\end{array}$ & $\begin{array}{c}\text { Respondents } \\
\mathbf{( F )}\end{array}$ & Percent & $(\mathbf{X}) *(\mathbf{F})$ \\
\hline Below-4 & $2-4$ & 3 & 80 & 30.8 & $\mathbf{2 4 0}$ \\
$\mathbf{4 - 6}$ & $4-6$ & 5 & 72 & 27.7 & $\mathbf{3 6 0}$ \\
\hline $\mathbf{6 - 8}$ & $6-8$ & 7 & 46 & 17.7 & $\mathbf{3 2 2}$ \\
\hline 8-Above & $8-10$ & 9 & 62 & 23.8 & $\mathbf{5 5 8}$ \\
\hline Total & & & 260 & 100.0 & $\sum\left(\mathrm{X}^{*} \mathrm{~F}\right)=1480$ \\
\hline
\end{tabular}




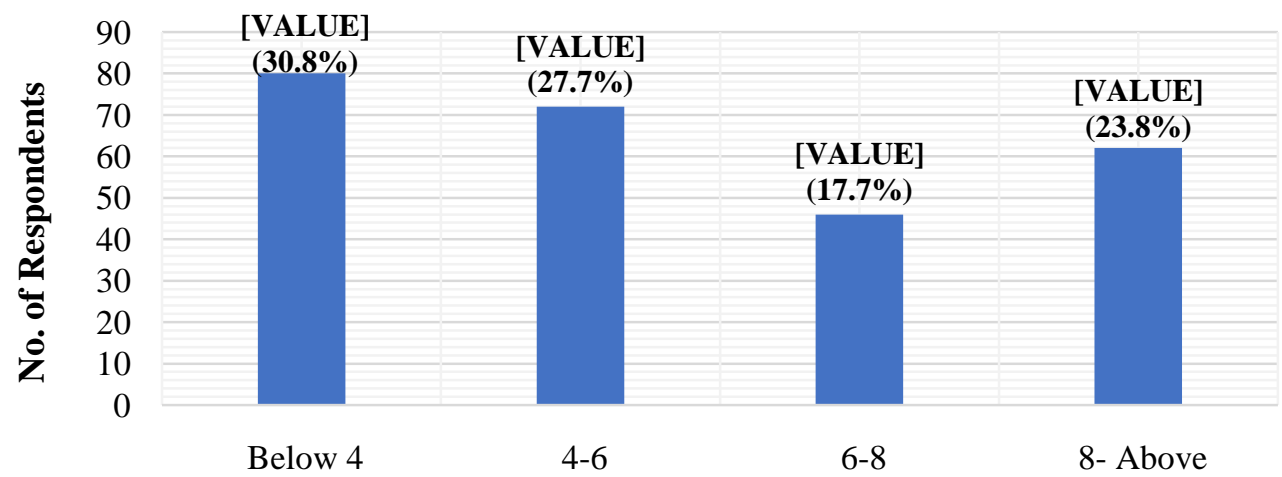

No. of Pieces Disnose

\section{Figure 4. Status of Unwanted and Used clothes}

In response to question 12 which enquired the quantity of clothes disposed by respondents in a year, the above table computes the pieces of unwanted or used clothes disposed of by respondents in a year. It contains different options of quantities (Below-4, 4-6, 6-8, 8-above) of clothes or disposed pieces, out of which respondent had to select any one according to the quantity disposed by them in a year. The table shows that out of 260 people $80(30.8 \%)$ people dispose Below-4 pieces, 72 (27.7\%) dispose $4-6$ pieces, $46(17.7 \%)$ dispose $6-8$ pieces and 62 $(23.8 \%)$ dispose 8 or more pieces in a year. In the above table the first and the last classes are open-ended, first is open at the lower end and last at the upper end. For statistical calculation the open ends were closed and to maintain regularity in class intervals we assume the same magnitude or difference inopen end classes as in the other equal classes. The assumption depends upon the class interval following the first class and preceding the last class (Gupta, S. P. 1969; Gupta, K. L. 1993-94). The new class intervals $(2-4,4-6$, $6-8,8-10)$ are fixed by taking the magnitude of 4-6, 6-8 class i.e. 2. Mid values are calculated to apply simple statistics in continuous series i.e. $(\Sigma$ $\left.\mathrm{X}^{*} \mathrm{~F}\right)$. The total approximate quantity of clothes disposed of by 260 people in a year i.e. 1480 pieces is derived. By dividing the total quantity with the number of respondents i.e. 260 we may conclude that, on an average a single respondent disposes around 6 pieces in a year.

Section 3:It consists of 7 questions (13 to 19) that inquire about the awareness, advantages and obstacles of Circular Economy.

Table 6: Percentage of respondents who thought about recycling of waste, want to put efforts \& know the techniques to reduce waste and also provide details about the awareness and desire for adoption of Circular Economy.

\begin{tabular}{|c|c|c|c|c|}
\hline Question No. & Questions & & Frequencies & Percentage \\
\hline \multirow{3}{*}{13} & \multirow{3}{*}{$\begin{array}{l}\text { Thought about recycling and } \\
\text { reuse of unwanted or used } \\
\text { clothes }\end{array}$} & Yes & 201 & 77.3 \\
\hline & & No & 59 & 22.7 \\
\hline & & Total & 260 & 100.0 \\
\hline \multirow[b]{2}{*}{14} & \multirow{2}{*}{ Want to put efforts to reduce } & Yes & 161 & 61.9 \\
\hline & & No & 99 & 38.1 \\
\hline
\end{tabular}




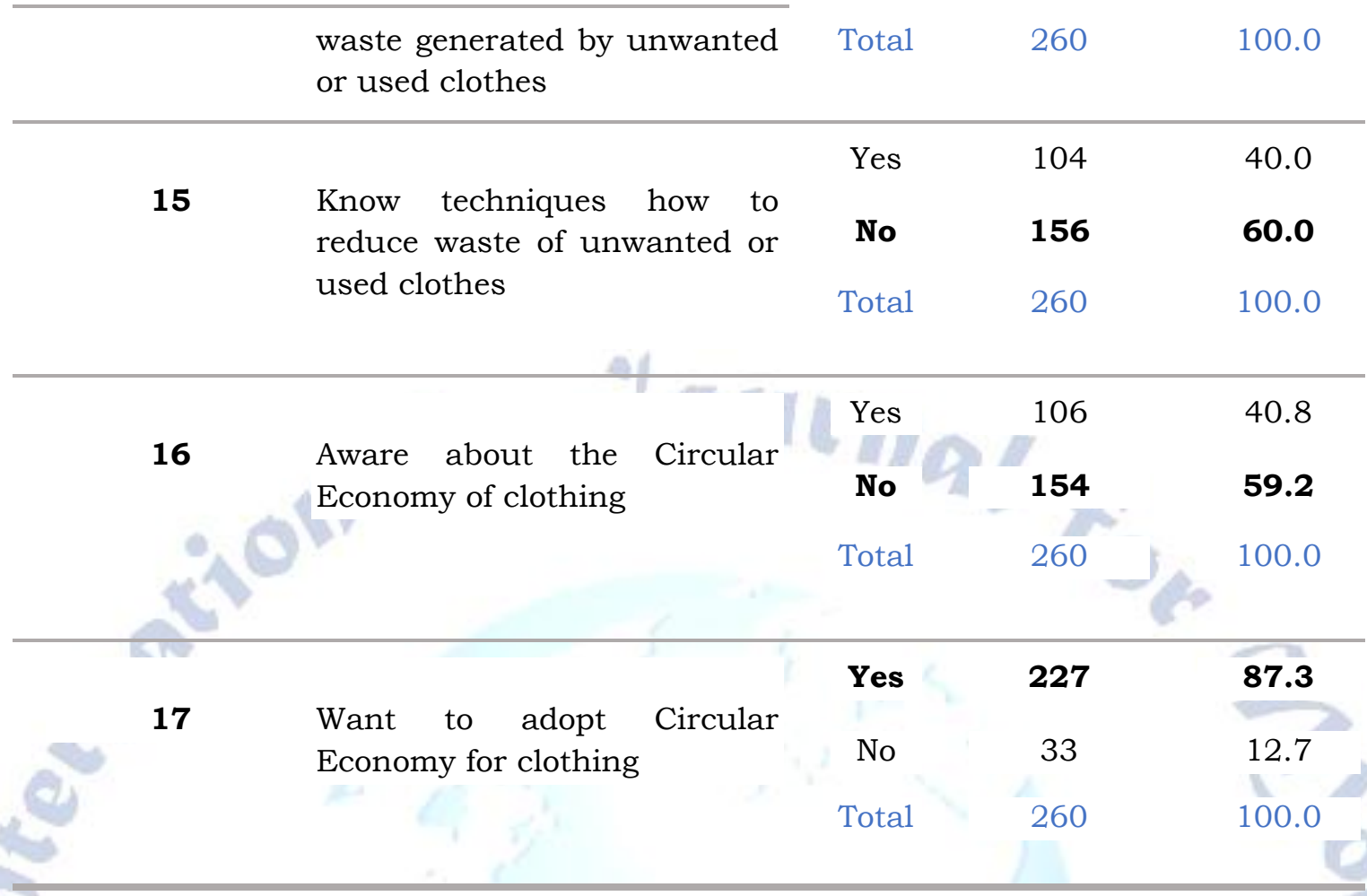

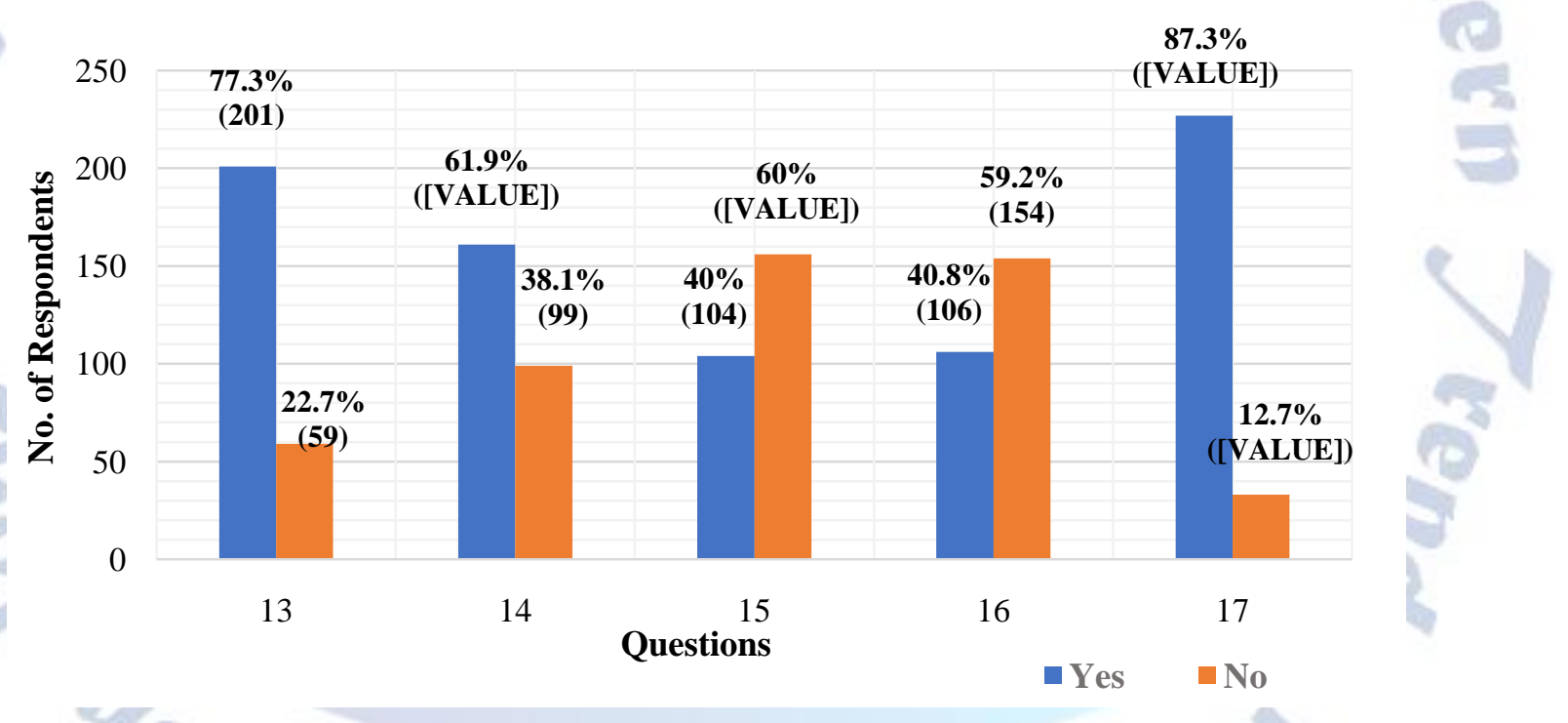

Figure 5. Response of Question No. 13, 14, 15, 16 and 17

Out of 260 respondents 201 (77.3\%) respondents agree to the recycling and reuse of unwanted or discarded clothes and 161 (61.9\%) are willing to put their efforts to reduce the waste of unwanted clothing but $156(60 \%)$ respondents are not aware of the techniques to reduce, recycle and reuse their unwanted clothes. According to the question no. 16 and 17 out of 260 respondents only 106
$(40.8 \%)$ are aware but majority of respondents $154(59.2 \%)$ are unaware about the Circular Economy of clothing but after understanding the definition of Circular Economy and its advantages provided in the survey form, 227 (87.3\%) respondents wanted to adopt Circular Economy for better environmental reasons. 
Table 7: Perception of respondents regarding adoption of the Circular Economy.

\begin{tabular}{|c|c|c|}
\hline Options & $\begin{array}{l}\text { Question no. 18: I want to adopt Circular econor } \\
\text { for my unwanted and used clothes because: }\end{array}$ & Mean \\
\hline 18.A & It reduces cost of buying and producing new clothes & 3.44 \\
\hline 18.B & It reduces pollution by reducing amount of waste & 3.78 \\
\hline 18.C & It helps in preserving natural resources & 3.84 \\
\hline 18.D & It creates a strong economy & 3.70 \\
\hline
\end{tabular}
Options Question no. 19: According to me the obstacles or Mean challenges in adoption of Circular economy is due to:

\begin{tabular}{lll}
\hline 19.A & Cost of implementation. & $\mathbf{3 . 1 5}$ \\
19.B & Lack of technical support. & $\mathbf{3 . 5 8}$ \\
19.C & Training requirements. & $\mathbf{3 . 6 2}$ \\
19.D & Surrounding environment. & $\mathbf{3 . 5 9}$ \\
19.E & Lack of government support & 3.78 \\
\hline
\end{tabular}

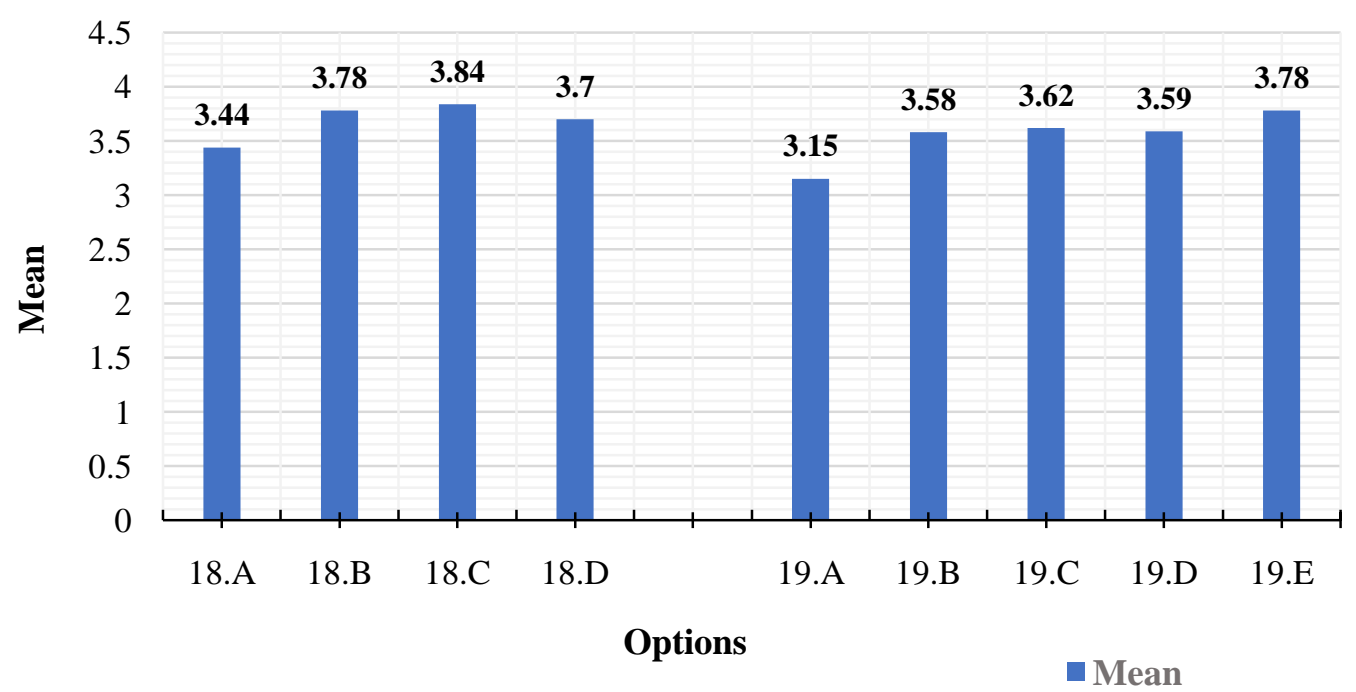

Figure 6. Mean status of Question No. 18 and 19 
After statistically analyzing the above responses, it is concluded that consumers perceive that adopting Circular Economy would majorly help in preserving our natural resources $($ Mean $=3.84)$ which could be used as raw material, apart from other benefits. Yet the biggest obstacle in adopting Circular Economy is the lack of government support (Mean $=3.78$ ).

\section{B. Discussion}

Statistical analysis concludes that the most common reason for the accumulation of post-consumer textiles waste is when respondent's clothes either are worn out, become defective or have fitting issues as in case of kids. Apart from reusing for household purposes (as in most of the cases), some modify clothing into utility items e.g. doormats, curtains, cushion covers, quilts, napkins, dusters etc. Due to lack of other provisions for disposal, the majority of people donate them to the poor, which forms a popular social practice in India. But then, where does it goes after being used by the poor? Once unfit for them it is thrown to add to the municipal landfills, to further the environmental problems. So, ultimately it becomes the last resort for every consumer. The reasons that support this behaviour is non or meagre availability of other options like second hand purchase stores, recycle drop box, thrift stores to buy discarded clothes, etc. Easiest is to donate either to poor or charity organizations. Unawareness about any waste management company who provide home pick up services of waste collection and its utilization adds to the problem.

Table 5 calculated that 260 people generate around 1480 pieces of textile waste and on an average a single person disposes around 6 pieces in a year. On this basis, it may easily be estimated how much Post-consumer textile waste may be generated by one village, city, state and a country. In this study we collect sample from top 5 populated cities of India as per 2011 census of India, theseare Mumbai with 1,83,94,912, Delhi with 1,63,49,831, Kolkata with $1,40,35,959$, Chennai with $86,53,521$ and Bangalore with 85,20,435 population (Office of the Registrar General and Census Commissioner, India., 2011). The total population of these cities in 2011 was $6,59,54,658$ and the city produced approximately $39,57,27,948$ pieces of waste every year. If estimated for whole India, the gravity of the problem can be assessed on the basis of this huge quantity piling every year.

Countries like China and other utilize this waste as a raw material by adopting Circular Economy in its textile and textile-based production processes which is nearlymissing in many other countries like in India. It's imperative from such nations that Circular Economy is the solution of Post-consumer textile waste. But according to this survey it's found that around $59.2 \%$ (table 6) respondents in selected cities of India are not aware about this concept. But at the same time, they are concerned about textiles waste and possess inclination to reduce it. Once they were explained the benefits of Circular Economy, they enthusiastically wanted to adopt it (table 6) to preserve natural resources and contribute to a clean society and environment (table 7). They agreed that though there exists lack of technical support, high cost of implementation,negligible trainingand lack of government support is the biggest obstacle in its adoption (table 7). It may be drawn that post-consumer textile waste can be put to better use if the mentioned obstacles are worked upon.

\section{CONCLUSIONS AND FUTURE RESEARCH DIRECTION}

Previous researches highlighted that though the textiles industry is providing for basic human needs in addition to fashion, healthcare, automobiles and beyond (Sivaram, et al., 2019), at the same time is a source of waste, and pollution (Chen-ke, et al., 2019), which is an environmentally damaging process, consuming vast quantities of natural resources like water, oil, land, toxic chemicals and emitting large amounts of carbon dioxide (Dobilaite, et al., 2017).Further reviews revealed how Circular Economy assists in economizing resource utilization, promotes ideal use of Pre- and Post-Consumer textile waste on one side and enables a sustainable environment on the other side (Assmuth, et al., 2011). So, it becomes necessary to understand and identify the opportunities in terms of circular economy (Will, et al., 2017) and stimulate the same for a healthy future. Accordingly, the study investigates the use and awareness regarding Circular Textiles Economy in India as well as people's inclination towards it.

The findings reveal that the majority of people discard their worn-out clothes, in vast quantities annually, by either donating or recycling into household use due to lack of knowledge and alternative avenues available in favour of Circular Economy. Though people are concerned and have willingness to adopt steps in this direction, there are minimal existence of discourses and facilities 
like: second hand purchase stores/units, recycle drop box/ bins, thrift stores to buy discarded clothes, units reusing and reproducing new clothes from old material, etc. So there remains little option other than charity, resulting ultimately into textiles landfills which further damages the environment for many numbers of years. The study further exhibits the willingness towards the adoption of Circular Textiles Economy.

The findings of the study contribute to the existing literature in this domain,exploring the disposition of worn out clothes in India and awareness regarding Circular Economy amongst people. The major contribution of the study is that it is conducted in India, where very few or no research is done in this field. The results are particularly very relevant for young start-up's and entrepreneurs who can use these findings to enter into ventures that may be challenging but profitable as there is almost no competition in the Circular Textiles Economy in India. Multinational investors from developed countries also hold good opportunities as India lacks technical know-how in this field. In addition to investments, technology from developed nations is very crucial. Once industry starts establishing and expanding, awareness and perfect utilization amongst consumers will develop on its own.

So, the Circular Economy is a sine qua non for a healthy environment.Indian Government must take up the concerns regarding post-consumer textiles waste at priority. It becomes essential to encourage investment on plants, technology and training in context to the Circular Economy, via policy framework and provisions for entrepreneurs. Public Private Partnership (PPP) can be a good model to start off with, with the government providing capital and technology, which is required in huge quantities. Tax benefits, exemptions \& subsidies, in addition to capital and know-how at subsidized rate may be floated to the private players to attract them to the venture which is almost missing in India. Other related businesses such as second-hand purchase stores, recycle drop box, thrift stores who buy discarded clothes, bins installation at certain points in the city to drop discarded or rejected clothes must be prompted amongst small and medium scale entrepreneurs. On the other side textiles consumers need to be educatedthrough advertisements regarding a healthy environment that can be a resultant of Circular Economy. These measures will ultimately help in producing sustainable textile and creating a sustainable environment via Circular Economy.

As the study has its limitations of being conducted in top 5 populated cities of India with a limited sample size, it is recommended that further studies include more cities of India with a larger sample size. A comparative analysis can be done with other countries who practice Circular Economy. This will help to identify the shortcomings and how to overcome them. Further, study design could consider using additional research methods, involving producers and investors to understand their lack of interest and ventures in the Circular Textiles Economy.

\section{REFERENCES}

1. Agarwal, R., \& Saran, M. (2015). Municipal Textile Waste and Its Management. Research Journal of Family, Community and Consumer Science, Vol. 3(1), 4-9.

2. Almeida, C., Santos, A., Bonilla, S., Giannetti, B., \& Huisingh, D. (2013.). The roles, perspectives and limitations of environmental accounting in higher educational institutions: an energy synthesis study of the engineering programme at the Paulista University in Brazil. Journal of Cleaner Production, 52, 380-391.

3. Assmuth, T., HäKkinen, P., Heiskanen, J., KautTo, P., LindH, P., MatTila, T., \& SAARINEN, K. (2011). Risk MANAGEMENT AND GOVERNANCE OF CHEMICALS IN ARTICLES. CASE STUDY OF TEXTILES. FINNISH ENVIRONMENT, 16/2011.

4. Bairagi, N. (2014). Recycling of Textiles in India. Journal of Textile Science \& Engineering, 3.

5. Beitch, S. (2015). The North face incorporates REPREVE Technology into Denali Jacket [Online]. Available at https://sourcingjournalonline-com.prox.lib.ncsu.edu/north-f ace-incorporates-repreve-technology-denali-jacket-sb/.

6. Berthon, M. A. (2016). TEXTILE WASTE COMES IN MANY FORMS. COOPER HEWITT. Retrieved November 28, 2019, from

https://www.cooperhewitt.org/2016/11/15/textile-waste/

7. Bhattacharjee, A. (2011). Waste Management in the Textile Industry, retrieved on 5, January, 2020 from www.fibre2fashion.com

8. Bing, X., Bloemhof-Ruwaard, J., Chaabane, A., \& van der Vorst, J. (2015). Global reverse supply chain redesign for household plastic waste under the emission trading scheme. Journal of Cleaner Production, 103, 28-39.

9. Birtwistle, G., \& Moore, C. M. (2007). Fashion clothing-Where does it all end up? International Journal of Retail \& Distribution Management, 35, 210-216, doi:10.1108/09590550710735068.

10. Bostanci, S., Limbachiya, M., \& Kew, H. (2018). Use of recycled aggregates for low carbon and cost-effective concrete construction. Journal of Cleaner Production, 189, 176-196. 
11. Boström, M., \& Micheletti, M. (2016). Introducing the sustainability challenge of textiles and clothing. J. Consum. Policy, 39(4), 367-375., doi:10.1007/s10603-016-9336-6.

12. Boulding, K. (1966), "The Economics of the Coming Spaceship Earth", in H. Jarrett (ed.), Environmental Quality in a Growing Economy, Baltimore: Johns Hopkins University Press, 1966: 3-14.

13. Bukhari, M., Carrasco-Gallego, R., \& Ponce-Cueto, E. (2018). Developing a national programme for textiles and clothing recovery. Waste Manag. Res, 36(4):321-331. doi: $10.1177 / 0734242 X 18759190$

14. Chen-ke, Xu., Hua, Cheng., Zhong-ju, Liao., \& Hao, Hu. (2019). An account of the textile waste policy in China (1991-2017). Journal of Cleaner Production, doi: 10.1016/j. Jclepro.2019.06.283

15. Cuc, S., and Vidovic, M. (2011). Environmental Sustainability through Clothing Recycling. Operations and Supply Chain Management, 4 (2/3), 108-115.

16. Cyberpac, D. (2013). Towards the Circular Economy, The Ellen MacArthur Foundation Report, 22-23, retrieved from www.ellenmacarthurfoundation.org

17. Dahlbo, H., Aalto, K., Eskelinen, H., \& Salmenpera, H. (2017). Increasing textile circulation- Consequences and requirements. Sustainable Production and Consumption, Volume 9 ,

Pages 44-57,https://doi.org/10.1016/j.spc.2016.06.005

18. Dias, P., Machado, A., Huda, N., \& Bernardes, A. (2018). Waste electric and electronic equipment (WEEE) management: A study on the Brazilian recycling routes. Journal of Cleaner Production, 174, 7-16.

19. Dobilaite,V., Mileriene, G., Juciene, M., Saceviciene, V., (2017). "INVESTIGATION OF CURRENT STATE OF A PRE-CONSUMER TEXTILE WASTE GENERATED AT LITHUANIAN ENTERPRISES", INTERNATIONAL JOURNAL OF CLOTHING SCIENCE AND TECHNOLOGY, VOL. 29 ISSUE: 4, PP.491-503, HTTPS://DOI.ORG/10.1108/ IJCST-08-2016-0097

20. Esha, C. (2016). India: Two Entrepreneurs Turn Waste into A Business, Forbes, retrieved on 21.02.2020 from https://www.forbes.com/sites/eshachhabra/2016/07/28 two-entrepreneurs-turn-waste-into-a-business/\#befa9eb 38278

21. Ellen MacArthur Foundation. (2017). A New Textiles Economy: Redesigning Fashion's Future. Retrieved on October, 2019, from https://www.ellenmacarthurfoundation.org/publications/ a-new-textiles-economy- redesigning-fashions-future

22. Fashion, O. B. (2018). In Copenhagen, Gearing up for a Circular Fashion System. Denmark. Retrieved February 16, 2020, from https://www.businessoffashion.com

23. Fletcher, K. (2012). Durability, fashion, sustainability: The processes and practices of use. Fashion Pract.: J. Des. Create. Process Fashion, 4 (2), 221-238., 4 (2), 221-238.

24. Geissdoerfer, M. S. (2017). The Circular Economy-A new sustainability paradigm. Journal of Cleaner Production, 143

25. Govindan, K., Azevedo, S., Carvalho, H., \& Cruz-Machado, V. (2014). Impact of supply chain management practices on sustainability. Journal of Cleaner Production, 85, 212-225.

26. Gupta, K. L. (1993-94). Business Statistics (Fourteenth, 2014-15 ed.). Agra: Navyug Publication.

27. GUPTA, P. J. (2018). The story of textile waste- Reasons and solutions. International Journal of Applied Home Science, 20.

28. Gupta, S. P. (1969). Statistical Methods (Forty Second Revised, 2012 ed.). New Delhi: Sultan Chand \& Sons.

29. Hamed, J. (2019). Sustainable development by reusing recyclables in a textile industry including two collectors and three firms: A game-theoretic approach for pricing decisions. Journal of Cleaner Production, https://doi.org/10.1016/j.jclepro.2019.04.222.

30. Indian Textiles Report- Feb 2020, India Brand Equity Foundation, updated on March 2020, retrieved on 28,March,2020, https://www.ibef.org/industry/textiles.aspx

31. Kapila, P., \& Dhillon, B. (2019). MANAGEMENT OF POST CONSUMER TEXTILE WASTE. Amritsar: Textile value chain. Retrieved on June 13, 2019, from https://textilevaluechain.in/2019/03/08/management-ofpost-consumer-textile-waste/

32. Klemeš, J. (2012). Industrial water recycle/reuse. Current Opinion in Chemical Engineering, 1(3), 238-245.

33. Klemeš, J., Stehlik, P., \& Worrell, E. (2010). Waste treatment to improve recycling and minimise environmental impact. 267-270.

34. Koszewska, M. (2018). Circular Economy-Challenges for The Textiles and Clothing Industry. AUTEX Research Journal, Vol. 18, No 4. DOI: 10.1515/aut-2018-0023 (C) AUTEX. 337-347

35. Kreiger, M., Mulder, M., Glover, A., \& Pearce, J. (2014). Life cycle analysis of distributed recycling of post-consumer high density polyethylene for 3-D printing filament. Journal of Cleaner Production, 70, 90-96.

36. Laitala, K., Boks, C., \& Klepp, I. (2015). Making clothing last longer: A design approach for reducing the environmental impacts. Int. J. Des., 9 (2), 93-107.

37. Lau, Y. 1. (2015). Reusing pre-consumer textile waste. SpringerPlus, 4 (Suppl 2): O9.

38. Leng, Z., Padhan, R., \& Sreeram, A. (2018). Production of a sustainable paving material through chemical recycling of waste PET into crumb rubber modified asphalt. Journal of Cleaner Production, 180, 682-688.

39. Li, M., Liu, J., \& Han, W. (2016). Recycling and management of waste lead-acid batteries: a mini review. Waste Management \& Research, 34(4), 298-306.

40. McKinsey. (2015). Europe's circular economy opportunity. retrieved on November 2019, from https://www.mckinsey.com/business-functions/sustaina bility-and-resource-productivity/our-insights/europes-circ ular-economy-opportunity

41. Ministry of Textiles, Annual Report 2018-19, retrieved on 30, April, 2020, From http://texmin.nic.in/sites/default/files/Textiles-AnnualRe port2018-2019\%28English\%29.pdf

42. Minter, A. (2018). With new clothes as cheap as used ones, Panipat's recycling industry goes out of fashion. The Economic Times. Retrieved September 17, 2019, from, https://economictimes.indiatimes.com/small-biz/sme-sec tor/with-new-clothes-as-cheap-as-used-ones-panipats-rec ycling-industry-goes-out-of-fashion/printarticle/62517509 .cms

43. Mitali, R. (2019). Circular economy need of the hour to minimize textile waste: Study. AHMEDABAD: THE TIMES OF INDIA. Retrieved 02 05, 2020, from https://timesofindia.indiatimes.com/business/circular-ec onomy-need-of-the-hour-to-minimize-textile-waste-study/a rticleshowprint $/ 63583328 . \mathrm{cms}$

44. Mo, H., Wen, Z., \& Chen, J. (2009). China's recyclable resources recycling system and policy: A case study in Suzhou. Resour. Conserv. Recycl., 53(7): 409-419., doi: 10.1016/j.resconrec.2009.03.002.

45. Nunnally, J., \& Bernstein, I. (1994). The Assessment of Reliability. Psychometric Theory. 3, 248-292.

46. Office of the Registrar General and Census Commissioner, India. (2011). Population Census. Ministry of Home Affairs, 
Government of India. Retrieved March 15, 2020, from https://www.census2011.co.in/

47. Perry, R., Charlotte, B., Isabella, M., \& Bob, C. (2004). SPSS Explained. Routledge Taylor \& Francis Group London \& New York.

48. Polat, O., Capraz, O., \& Gungor, A. (2018). Modelling of WEEE recycling operation planning under uncertainty. Journal of Cleaner Production, 180, 769-779.

49. Prerna, J., \& Charu, G. (2018). The story of textile wasteReasons and solutions. International Journal of Applied Home Science, 871-890.

50. PRERNA, J., \& CHARU, G. (2016). TEXTILE RECYCLING PRACTICES IN INDIA: A REVIEW. International Journal of Textile and Fashion Technology (IJTFT), 21-35.

51. Rahimi, M., \& Ghezavati, V. (2018). Sustainable multi-period reverse logistics network design and planning under uncertainty utilizing conditional value at risk (CVaR) for recycling construction and demolition waste. Journal of Cleaner Production., 172, 1567-1581.

52. REDRESS. (2014). THE ECOCHIC DESIGN AWARD SOURCING OF TEXTILE WASTE.Retrieved February 12, 2020, from www.ecochicdesignaward.com

53. Resta, B., Gaiardelli, P., Pinto, R., \& Dotti, S. (2016). Enhancing environmental management in the textile sector: An organisational-life cycle assessment approach. Journal of Cleaner Production, 135, 620-632.

54. Sandin, G., \& Peters, G. (2018). Environmental impact of textile reuse and recycling-A review. Journal of Cleaner Production.

55. Sivaram, N.M., Gopal, P.M., \& Barik, D. (2019). Toxic Waste from Textile industry. Energy from Toxic Organic Waste for Heat and Power Generation, 43-54, https://doi.org/10.1016/B978-0-08-102528-4.00004-3

56. Snoek, S. (2017). Circular Economy in the Textile Industry: Transition theory in Dutch start-ups towards a circular economy. Wageningen UR, iv.

57. Statista. (2018) Global apparel market size projections from 2012 to 2025, by region (in billion U.S. dollars). Available at: https://www.statista.com/statistics /279757/apparel-mar ket-sizeprojections-by region/ [Accessed January 2018].

58. Symposium, C. E. (2018). Accelerating India's Circular Economy Shift, A Half-Trillion USD Opportunity-Future-proofing growth in a resource-scarce world. The Federation of Indian Chambers of Commerce and Industry, FICCI. Retrieved August 28, 2019, from www.ficcices.in

59. Vasileios, R., Arno, B., Terri, K., Martin, H.G., \& Anastasia, I. (2015). The Circular Economy: Barriers and Opportunities for SMEs.

60. Walter, L. F., Dawn, E., Sara, H., David, T., Valerie, B., \& Arminda. (2019). A Review of the socio-economic advantages of textile recycling. Journal of Cleaner Production, 26.

61. Wijkman, A., \& Skånberg, K. (2016). The Circular Economy and Benefits for Society. Club of Rome and Mava Foundation. Available at: https://www.clubofrome.org/wpcontent/ uploads/2016/03/The-Circular-Economy-and-Benefits-for -Society.pdf

62. Will, M., Yong, G., Beijia, H., Eva, B., Raimund, B., Serdar, T., Rene. K., \& Teresa, D. (2017). Circular Economy Policies in China and Europe. Journal of Industrial Ecology, doi: $10.1111 /$ jiec. 12597

63. Xu, C. k., Chen, H., Liao, Z. j., \& Hu, H. (2019). An account of the textile waste policy in China (1991-2017). Journal of Cleaner Production, 25.
64. Zamani, B. (2014). Towards Understanding Sustainable Textile Waste Management: Environmental impacts and social indicators. Thesis submitted to Chalmers University of Technology, Gothenburg, Sweden. Available at: http://publications.lib.chalmers.se/records/fulltext/2045 02/204502.pdf. 